\title{
Reading for the dignity of all: Overcoming the troubling legacy of the Old Testament
}

\author{
Claassens, L Juliana \\ Stellenbosch University \\ jclaassens@sun.ac.za
}

\begin{abstract}
In light of the numerous instances in the Hebrew Bible in which the dignity of its characters are threatened, violated or potentially violated, this article seeks to identify a number of strategies that may be used to read the Bible for the dignity of all so overcoming the Old Testament's troubling legacy. These strategies have been inspired by the work of Martha Nussbaum who, in one of her recent books, The New Religious Intolerance: Overcoming the Politics of Fear in an Anxious Age, names three principles that may help a society to become more compassionate in nature and to transcend, what she calls, a narcissistic notion of fear: (1) Political (and I would add religious) principles that express equal respect and dignity for all people (2) Rigorous critical thinking that criticizes inconsistencies that may lead to human rights violations (3) Developing an empathetic or participatory imagination, in which one is able to consider how the world looks from the point of view of a person of a different cultural or religious point of view.
\end{abstract}

\section{Keywords}

Violence in the Old Testament, Compassion, Martha Nussbaum, Old Testament Ethics. Human Dignity

\section{Introduction}

So God created humankind in God's image, in the image of God, God created them; male and female God created them (Gen 1:27)

Thus reads probably one of the most compelling texts in the Old Testament, which has been the source of some rich theological reflection by both 
Jewish and Christian interpreters on what has been called the Imago Dei, ${ }^{1}$ i.e., the theological claim that professes the inherent worth of every human being whose dignity is a gracious gift bestowed by the Creator God. ${ }^{2}$

And yet the Hebrew Bible contains numerous instances in which the worth or dignity of its characters are threatened, violated or potentially violated, creating a situation of dehumanization in which the human ability to flourish is severely restricted and impaired. As Carol Fontaine rightly notes, Judaism, Christianity and Islam have in common that, even though the notion of the "inherent worth and dignity of every person" is a key principle that is explicitly and/or implicitly present in all these Scriptures, it "has been honoured more in its breach than in its practice."

Fontaine continues that the biblical record on human rights for women and girls in particular has been abysmal in these "classical religions of the Book," given that "each faith was traditionally interpreted in a gender-biased or culturally parochial fashion." ${ }^{\text {"T }}$ This is clearly evident in what famously has been called "Texts of Terror" to cite a classic book by Phyllis Trible. ${ }^{5}$ So we find in the Hebrew Bible terrifying stories that narrate the violent rape and murder of the Levite's Wife (Judges 19), the rape of King David's daughter Tamar by her half-brother Amnon (2 Samuel 13), the tragic end the Daughter of Jephthah met due to her father's stupidity (Judges 11), and many equally disturbing accounts. Moreover, to these narrative accounts

1 For an overview of the various ways in which the Imago Dei functions in the Hebrew Bible, cf. Hendrik Bosman, "Figuring God and Humankind: The Imago Dei in View of Anthropologies in the Old Testament," in Fragile Dignity: Intercontextual Conversations on Scriptures, Family and Violence (ed. L Juliana Claassens and Klaas Spronk; Atlanta, GA: SBL, 2013), 39-56.

2 The language of human dignity that maintains that people regardless of factors such as race, class, gender, sexual orientation, physical or mental abilities possess intrinsic value and as such are deserving of equal and just treatment has found its way into the preamble to the United Nations declaration of Human Rights, which affirms the inherent rights of all human beings in terms of "the dignity and worth of the human person and in the equal rights of men and women." Moreover, a number of countries including South Africa has taken up the language of human dignity in their constitutions (cf. Chapter 2.10 of the South African Bill of Rights that states: "Everyone has inherent dignity and the right to have their dignity respected and protected").

3 Carole R Fontaine, With Eyes of Flesh: The Bible, Gender and Human Rights (Bible in the Modern World 10; Sheffield: Sheffield Phoenix Press, 2008), 13.

4 Fontaine, With Eyes of Flesh, 26.

5 Phyllis Trible, Texts of Terror: Literary-Feminist Readings of Biblical Narratives (Philadelphia: Fortress Press, 1984). 
of dehumanization, one could add the prophetic metaphor of God as an abusive spouse who is depicted as being justified in punishing his wife Judah/Jerusalem - the violent destruction of Jerusalem and the brutal torture of her population during the Babylonian invasion compellingly, though quite unfortunately, captured in the metaphor of domestic violence (e.g. Hosea 1-2; Jeremiah 2-3; Ezekiel 16, 23). ${ }^{6}$ As feminist scholars have shown, the danger of this particular metaphor is situated in the fact that metaphors have a powerful world-shaping effect. Metaphors drawing their connotations from the semantic fields of domestic and sexual violence have been shown to be remarkably successful in creating a world in which women are treated as second class citizens and where violence against women is implicitly and sometimes even explicitly propagated. ${ }^{7}$

Of course the violent legacy of the Hebrew Bible is not limited to its treatment of its female characters. Much work has been done in facing the role of the Bible in justifying war, ${ }^{8}$ legitimizing colonialism, ${ }^{9}$ creating a homophobic world where gays' and lesbians' very being is at risk ${ }^{10}$ as well as justifying slavery in the American South. ${ }^{11}$ Womanist theologian Renita Weems tells the story of the African American philosopher Howard Thurman's grandmother, an ex-slave who never learnt to read, who refused to listen to anything read to her from Paul. The reason for this is that biblical texts typically associated with Paul, such as Colossians 3:22 and

6 Much has been written about the use of sexual violence in the Prophets. To mention a few classic examples: Renita Weems, Battered Love: Marriage, Sex, and Violence in the Hebrew Prophets (Minneapolis: Fortress Press, 1995); Cheryl Exum, "The Ethics of Biblical Violence against Women," In The Bible in Ethics: The Second Sheffield Colloquium (ed. John William Rogerson and Daniel Carroll. Sheffield: Sheffield Academic Press, 1995); Linda Day, "Rhetoric and Domestic Violence in Ezekiel 16," Biblical Interpretation 8 (2000): 205-229; Nancy Bowen, "Women, Violence and the Bible," In Engaging the Bible in a Gendered World: An Introduction to Feminist Biblical Interpretation in Honor of Katharine Doob Sakenfeld (ed. Linda Day and Carolyn Pressler. Louisville, KY: Westminster John Knox, 2006), 186-199.

7 Cf. Mary E Shields who argues that the sexualized violence in a text like Ezekiel 16 occurs "'in the sight of many women' (v 41), her raped and mutilated body becomes an object lesson for others of her gender," "Multiple Exposures: Body Rhetoric and Gender Characterization in Ezekiel 16," JFSR 14 (1998): 12.

8 Eric Seibert, The Violence of Scripture: Overcoming the Old Testament's Troubling Legacy (Minneapolis: Fortress Press, 2012), 16-18.

9 Seibert, The Violence of Scripture, 18-19.

10 Seibert, The Violence of Scripture, 22-23.

11 Seibert, The Violence of Scripture, 19. 
Ephesians 6:5 that tell slaves to be obedient to their masters, had been used to tell her generation and before that slaves should submit to their masters. ${ }^{12}$ And in our South African context, we continue to bear the scars of the troubling legacy of the Bible. As Elelwani Farisani recently has reminded a new generation of readers, the Bible has played an unfortunate role in the history of Apartheid in South Africa when texts such as the Tower of Babel in Gen 11:1-8, Deut 32:8 and Acts 2:8 were used to justify, and even "prove" Apartheid. ${ }^{13}$

Nevertheless, the language of human dignity and the theological claim of equality and human worth is an idea that shines through the numerous stories of dehumanization that fill the pages of the Bible - its significance extending beyond its original context urging contemporary Bible readers to read otherwise. ${ }^{14}$ In this regard, reading the Bible for the dignity of all requires some reading strategies to, as Eric Seibert has said it well in the subtitle of his recent book of Violence in the Old Testament, "Overcom[e] the Old Testament's Troubling Legacy." ${ }^{15}$

Now there are different options for dealing with this troubling legacy of the biblical text. Like Howard Thurman's grandmother who refused to listen to anything read to her by Paul, many believers have an explicit or implicit "canon within canon" when they bracket certain texts that are troubling or confusing to them. Metaphorically speaking, it would be like ripping some pages or whole sections out of the Bible. And actually there are a number

12 Renita J. Weems, "Reading Her Way through the Struggle: African American Women and the Bible," in Stony the Road We Trod: African American Biblical Interpretation (ed. Cain Hope Felder. Minneapolis: Fortress, 1991), 61-62.

13 Elelwani Farisani, "Interpreting the Bible in the Context of Apartheid and Beyond: An African Perspective," Studia Historiae Ecclesiasiticae 40/2 (2014): 207-225. Farisani in his analysis of the role of particular biblical texts in Apartheid theology draws heavily on the article by Christo Lombard, "Does Contextual Exegesis Require an Affirming Bible? Lessons from 'Apartheid' and 'Africa' as Narcissistic Hermeneutical Keys," Scriptura 101 (2009): 274-287. Cf. also the classic work by J A (Bobby) Loubser, The Apartheid Bible (Cape Town: Maskew Miller Longman, 1987).

14 James Luther Mays notes that even though the idea of the "image of God" occurs only twice in the biblical traditions, "its actuality is a structural theme of the biblical account of God and humankind," "The Self in the Psalms and the Image of God," in God and Human Dignity (ed. R Kendall Soulen \& Linda Woodhead; Eerdmans, 2006), 38-39.

15 Cf. the explanation of this subtitle that includes the rationale for writing this book in the introduction to his book, Seibert, The Violence of Scripture, 1-12. 
of feminist scholars who literally and very dramatically have walked away from the "religion of the fathers" and hence also its scriptures. ${ }^{16}$

However, as an Old Testament scholar, I would like to propose another way that does not throw the Bible out of the window, but actually engages the Bible more deeply. This act of reading occurs in light of the profound awareness of the challenges in our own context that as noted above include the ongoing dehumanization of many of our brothers and sisters near and far. In this regard, biblical texts may serve as an important space for moral reflection, which as a result, may encourage the reader to return to the world with an even greater resolve to change the world from the way it is to the way it is supposed to be.

But what is it that shapes our eyes for reading? I have been very much influenced by Martha Nussbaum's use of literature to help readers deal with the challenges of their own context. In one of her recent books, The New Religious Intolerance: Overcoming the Politics of Fear in an Anxious Age, Nussbaum names three principles that may help a society to become more compassionate in nature and to transcend, what she calls, a narcissistic notion of fear: (1) Political (and I would add religious) principles that express equal respect and dignity for all people (2) Rigorous critical thinking that criticizes inconsistencies that may lead to human rights violations (3) Developing an empathetic or participatory imagination, in which one is able to consider how the world looks from the point of view of a person of a different cultural or religious point of view. ${ }^{17}$

In this article, I would like to identify a number of strategies that I have found helpful in my own journey to read the Bible for the dignity of all as inspired by the work of Nussbaum and others who have been committed to cultivating more just societies.

16 Mary Daly, Gyn/Ecology: The Metaethics of Radical Feminism (London: Women's Press, 1978).

17 Martha C Nussbaum, The New Religious Intolerance: Overcoming the Politics of Fear in an Anxious Age (Cambridge, MA: Bellknap Press, 2012), 2-3. 


\section{Dignity promoting reading strategies}

\section{a) Equal bearers of human dignity}

The starting point for Martha Nussbaum's reflection on what it will take to overcome religious intolerance that increasingly has led to some gross human rights violations is the basic assumption widely shared by people "that all human beings are equal bearers of human dignity." Even though "people may be unequal in wealth, class, talent, strength, achievement, or moral character," they are "equal as bearers of inalienable basic human dignity that cannot be lost or forfeited." 18 Nussbaum continues to modify this initial definition of human dignity in light of the critique that states that in the human dignity discourse there has been an overemphasis on reason as condition for our humanity. This point of critique comes especially from within a context of disability where humans with lessened mental capabilities are no less worthy of equal dignity and respect. Nussbaum thus extends her initial definition of being human to include the capacity to perceive, the capacity to move, the capacity to feel emotions, the capacity to love and care which would as a result include a whole range of physical and mental capabilities. ${ }^{19}$

What is interesting about Nussbaum's starting point is that in terms of political philosophy, she proposes that there are some principles or convictions, or one can say in religious terms, beliefs, that serve as a framework for the way one views people around us. This basic principle of an inherent human dignity shared by all people is also present in Carol Fontaine's approach that seeks to read the Bible in terms of a human rights framework when she argues that central to an act of biblical interpretation that is committed to fostering a human rights culture, there is a starting point that assumes that human rights "belong to every human simply by virtue of being born human." ${ }^{20}$ She argues as follow:

By the very fact of existence, all (created) life-forms have the inherent worth of simply being embodied here. Some may claim that 'what exists' is here because God created it so, and blessed

18 Nussbaum, New Religious Intolerance, 61.

19 Nussbaum, New Religious Intolerance, 64.

20 Fontaine, With Eyes of Flesh, 8. 
the creation. Others may reject that account, choosing instead the complexities of evolution and science as explanation, but that does not obviate the ethical implications of the existence of being. From either perspective, religious or secular, the evidentiary function of simply being, as a part of known creation, conveys a dignity proper to whatever form of existence we may be speaking of, and creates a duty in the one who perceives it. ${ }^{21}$

Several Old Testament scholars have used this point of departure in their exploration of themes of justice in the Old Testament. For instance, Thomas LeClerq focuses on the theme of justice to the poor that runs like a golden threat throughout the book of Isaiah, showing how justice in the various parts of the Book Isaiah is "inseparably tied to the social conditions of particular communities in specific circumstances." 22 And Leslie Hoppe explores how various parts of the Old and New Testament treat the notion of poverty, arguing for instance how the Torah makes significant efforts in ensuring that justice is done to the poor as evident in the foundational text in Deuteronomy 10:18 that describes God as "execut[ing] justice for the orphan and widow, and who loves the strangers, providing them food and clothing." 23

Moreover, an important theme that has been highlighted in Old Testament scholarship concerns the "Faith of the Outsider" to echo a book by Frank Spina by the same title. ${ }^{24}$ Considering that the basic criterion for having one's dignity recognized is the mere fact of being born, "the Other" is to be valued simply for being there. As Fontaine writes in this regard: "The Other does not need to disappear, to be done away with, or contained; the Other needs only to be acknowledged, truly and properly seen, through

21 Fontaine, With Eyes of Flesh, 29.

22 Thomas L LeClerk, Yahweh is Exalted in Justice: Solidarity and Conflict in Isaiah (Minneapolis: Fortress, 2001), 178.

23 Leslie J Hoppe, There Shall be No Poor Among You (Nashville, TN: Abingdon, 2004), 24-41, 173.

24 Frank Spina, Faith of the Outsider: Exclusion and Inclusion in the Biblical Story (Grand Rapids, MI: Eerdmans, 2005). In this book, Spina explores seven stories of "outsiders" who play a pivotal role in both the Hebrew Bible as well as the New Testament and which challenge us how we regard the numerous "others" with whom we share this world. 
the fleshy eyes of another embodied entity." ${ }^{25}$ In this regard, it is significant to see how many "Others" are taken up into Israel's narrative account of its own history. For instance, one reads in Genesis 16, 21 the complex and granted ambiguous story of Hagar who as the quintessential "Other" - her name in Hebrew meaning "the foreigner" (ha-ger) - is recognized by being fixed into Israel's memory. ${ }^{26}$ This woman, this foreigner, is humanized by the compelling account of Hagar weeping in the wilderness fearing the imminent death of her son. ${ }^{27}$ Moreover, this foreign woman emerges as the first "theologian" as Hagar becomes the first character in Genesis who names the Divine, calling God the God who sees, so calling on subsequent readers to also recognize the Others in their midst. Also the book of Ruth is concerned with the Moabite Other being brought into the Israelite community with Ruth becoming the grandmother of King David. In the book of Ruth one finds how a counterworld is created, a peaceable community in which, as Katharine Sakenfeld notes, "no one is to be left destitute," and young and old and also the marginalized are included. ${ }^{28}$

Such readings that are rooted in reading for the dignity of all is not oblivious to the complexity inherent to these narratives. For instance with regard to Hagar, subsequent interpreters, including Paul, have actually missed the rich potential in recognizing the Other, utilizing the figures of Sarah-Hagar in Galatians 4:21-31 in terms of an allegory explaining the life of grace vs life under law. As Letty Russell remarks: "In this new version of Genesis 16 and 21 Paul doubles Hagar's rejection through the use of allegory. In Genesis she is a foreigner, a slave, and a threat to Sarah. In Galatians, she is all of these and also a Jewish Christian opponent, a slave to the Jewish law, and a threat to Gentile Christian freedom in Christ." ${ }^{29}$

25 Fontaine, With Eyes of Flesh, 29.

26 Hagar has been very important in the African American tradition. Cf. e.g. Delores Williams, "Hagar in African American Biblical Appropriation," in Hagar, Sarah, and Their Children: Jewish, Christian, and Muslim Perspectives (ed. Phyllis Trible and Letty M. Russell; Louisville, KY: Westminster John Knox, 2006), 171-184.

27 L Juliana Claassens, "Just Emotions: Reading the Sarah and Hagar narrative (Genesis $16,21)$ through the Lens of Human Dignity', Verbum et Ecclesia 34/2 (2013), Art. \#787.

28 Katharine Sakenfeld, Ruth (Interpretation; Louisville, KY: John Knox, 1999), 87-88. Cf. also L Juliana Claassens, "Resisting Dehumanization: Ruth, Tamar and the Quest for Human Dignity,” Catholic Biblical Quarterly 74/4 (2012): 659-674.

29 Letty M Russell, "Twists and Turns in Paul's Allegory," in Hagar, Sarah, and Their Children: Jewish, Christian, and Muslim Perspectives (ed. Phyllis Trible and Letty M. Russell; Louisville, KY: Westminster John Knox, 2006), 72. 
Moreover, it has been shown by postcolonial interpreters how Ruth is hold up in the biblical witness as the model immigrant who should just leave her native customs behind and whose acceptance is determined on the basis of her ability to fully integrate into the dominant society. ${ }^{30}$ Actually, as we continue to read biblical texts with an eye toward human dignity, it is exactly these troubling parts of the text and its interpretation that draw our attention to the complexities involved in our contemporary conversations on what dignity for all means in our complex situations where there are often competing claims for justice. ${ }^{31}$

\section{b) Embracing critical thinking}

A second point highlighted by Nussbaum is the important principle of critical thinking in critiquing injustice. She argues that people often tend to make decisions in an uncritical way without much self-reflection. Hence, people's actions are often marred by what she describes "limited experience, by tradition and peer pressure, by fear...by self-interest and self-protective bias." In this regard, Nussbaum highlights the importance of "the examined life" in showing the inconsistencies in people's reasoning that may be responsible for human rights violations. ${ }^{32}$ Actually, the previous principle of "dignity for all" serves as the point of reference for such a process of critical thinking.

Biblical scholars who are committed to biblical readings that are ethical in nature, ${ }^{33}$ employ this same principle of embracing critical thinking in

30 Bonnie Honig, "Ruth the Model Emigree: Mourning and the Symbolic Politics of Immigration," in Ruth and Esther: A Feminist Companion to the Bible (Second Series) (ed. Athalya Brenner; Sheffield: Sheffield Academic Press, 1999) 50-74.

31 Cf. e.g. the quote by Palestinian Christian, Jean Zaru that captures this notion of competing claims of justice, "The Zionist dream became our nightmare. My experience as dispossessed Palestinian forced upon me an examination of such biblical land traditions. Does God promise land to one people at the expense of others and then give that people a divine mandate to cleanse the land of its inhabitants? A literalist reading of some of the earlier books of the Hebrew Bible frightens me simply as a human being. Yet the problem takes on a more immediate relevance when Jewish settlers come to the West Bank and other territories, confiscate the land, and take it for the exclusive use of Jews, claiming all the while that the land was given by God exclusively to Jews," Jean Zaru, "Biblical Teachings and the Hard Realities of Life," in Hope Abundant: Third World and Indigenous Women's Theology (ed. Kwok Pui-lan; Orbis, 2010), 126.

32 Nussbaum, New Religious Intolerance, 99.

33 Cf. the groundbreaking work done by Elisabeth Schüssler Fiorenza in her 1987 SBL Presidential address, "The Ethics of Biblical Interpretation: Decentering Biblical 
terms of the act of reading the Bible in light of widely accepted convictions or principles or beliefs such as justice, love of God, love of neighbour, and dignity for all. In this regard, Eric Seibert outlines a number of reading strategies that critically examine all those violent texts that are present in the biblical witness. Using Judith Fetterley's idea of the "resistant reader," Seibert argues that readers have the ethical obligation to read the Bible, and particular those texts that can be considered harmful, critically. ${ }^{34}$

This critical examining of the text is rooted among other in the internal critique present in many biblical texts - there is a rich tradition of innerbiblical conversation in individual texts as well as in terms of the canonical tradition subverting violent and xenophobic texts such as the infamous $\eta 9 \epsilon \rho \epsilon \mu$ law found in Deut 7:1-5 in which God commands Israel to utterly destroy the inhabitants of the Promised Land they are about to enter. ${ }^{35} \mathrm{~A}$ further strategy that may help the reader to embrace critical thinking is to read with the victims of the text - as Seibert suggests, e.g., from the perspective of the Egyptian widows and orphans after the destruction of the Egyptian army at the Red Sea. ${ }^{36}$ Or to imagine the children in these violent texts as Chris Heard has done in a fascinating article on the book Habakkuk that imagines the effect of violence on both children of the Israelites during the Babylonian invasion as well as the Babylonian children as evident in the call for revenge in Psalm 137: 9 which celebrates the ones who shall dash the heads of the Babylonian babies against the rocks. ${ }^{37}$ What is more, Seibert notes that this inclination to read with the victims in the text is coupled with the important act of reading from the margins, being attentive to the way in which biblical texts have caused great harm in terms of gender, race, sexuality and disability. ${ }^{38}$

Scholarship," JBL 107 (1988): 3-17.

34 Seibert, The Violence of Scripture, 66-67.

35 Seibert, The Violence of Scripture, 77-81. Cf. e.g. Book of Ruth subverting the claim in Deu 23:3 that "No Ammonite or Moabite shall be admitted to the assembly of the LORD. Even to the tenth generation, none of their descendants shall be admitted to the assembly of the LORD."

36 Seibert, The Violence of Scripture, 81-84.

37 Chris Heard, "Hearing the Children's Cries: Commentary, Deconstruction, Ethics, and the Book of Habakkuk," Semeia 77 (1997): 75-89.

38 Seibert, The Violence of Scripture, 85-86. 
Biblical scholarship has been greatly enriched by interpretations of the biblical text that have done exactly this. For instance, disability scholars have investigated the occurrence of disability within the biblical text in addition to using the diverse experience of people with disabilities as hermeneutical lens for reading texts. ${ }^{39}$ In particular texts that offer harmful stereotypes regarding disability are challenged, also by identifying counter biblical voices that offer an alternative kind of language regarding theology and disability. ${ }^{40}$ And in a recent volume called Bible Trouble: Queer Reading at the Boundaries of Biblical Scholarship, ${ }^{41}$ the contributors seek to challenge by means of "a critical interrogation, or active contestation," the ways in which the Bible has been used "to support heteronormative and normalizing configurations of sexual and gender practices and sexual and gender identities." ${ }^{2}$ These interpreters furthermore seek to reclaim the same Bible that so often has been used to hurt and exclude members of the respective LGBTIQ communities. ${ }^{43}$ Also my own work in terms of gender and the Old Testament, together with that of many other feminist interpreters, has been committed to biblical readings that counter harmful gender stereotypes as well as propose interpretations of the biblical texts that have to potential to be truly life-giving. This is exemplified also in my

39 Hector Avalos, Sarah Melcher, Jeremy Schipper (eds), This Abled Body: Rethinking Disabilities in Biblical Studies (Atlanta, GA: Society of Biblical Literature, 2007); Jeremy Schipper, Disability Studies and the Hebrew Bible: Figuring Mephibosheth in the David Story (New York, NY: T \& T Clark, 2006); Disability and Isaiah's Suffering Servant (Oxford, U.K.: Oxford University Press, 2011).

40 Cf. my essay in this regard, L Juliana Claassens, "Countering Stereotypes: Job, Disability and Human Dignity," Journal of Religion, Disability \& Health 17/2 (2013): 169-183.

41 Theresa J. Hornsby and Ken Stone, Bible Trouble: Queer Reading at the Boundaries of Biblical Scholarship (Semeia Studies 67; Atlanta, GA: SBL, 2011).

42 Ken Stone, "Queer Reading between Bible and Film: Paris is Burning and the 'Legendary Houses' of David and Saul," in Bible Trouble: Queer Reading at the Boundaries of Biblical Scholarship (ed. Theresa J. Hornsby and Ken Stone; Semeia Studies 67; Atlanta, GA: SBL), 94.

43 For instance, Manuel Villalobos uses the example of the Ethiopian eunuch, who despite being understood as "sub-human, inhuman, non-human" in terms of the criteria of his culture is able to engage in a liberating reading of the ancient scroll of Isaiah (Acts 8:2640). Drawing on his own struggle with the biblical text as site of exclusion, Villalobos considers ways in which the Bible may be read in terms of the borderland experience that makes up the reality of many members of the LGBTIQ communities to become once again a source of not just liberation but even joy, "Bodies Del Odro Lado Finding Life and Hope in the Borderland: Gloria Anzaldúa, the Ethiopian Eunuch of Acts 8:26-40, y Yo," in Bible Trouble: Queer Reading at the Boundaries of Biblical Scholarship (ed. Theresa J. Hornsby and Ken Stone; Semeia Studies 67; Atlanta, GA: SBL), 205-206, 212-216. 
current project on female resistance in the Old Testament in which I read six narratives that all portray female characters, who even though they find themselves trapped in circumstances that violate their self-worth, resist the indignity that had befallen them. In the process, each woman is, as the title for this new project suggests, "Claiming Her Dignity."

\section{c) Cultivating "Inner eyes"}

In the third instance, Nussbaum describes the importance of developing an empathetic or participatory imagination, in which one is able to consider how the world looks from the point of view of a person of a different religious or cultural tradition. In what she calls, "cultivat[ing] the inner eyes," Nussbaum talks about the importance of a "curious, questioning, and receptive demeanor that says, in effect, 'Here is another human being. I wonder what he (or she) is seeing and feeling right now."'44

Nussbaum has written extensively on the role of literature in forging this empathetic or participatory imagination. For instance, in her recent book, Political Emotions, she uses the term "tragic spectatorship" in which she describes the role of tragic stories in order to help people recognize the commonalities amongst themselves, what she calls, "the shared human possibilities rooted in bodily vulnerability." ${ }^{\prime 4}$ According to her, tragedy that emphasizes the bodily frailty of all human beings is an important element in encouraging compassion beyond one's narrow circle of concern. ${ }^{46}$ Hagar's pain at seeing her child about to die from thirst in Genesis 21 serves the purpose of humanizing the Other, drawing on the shared bodily frailty that as Nussbaum rightly points out "encourage[s] a compassion that overcomes tendencies to arrogant denial of mere humanity."

Moreover, tragic spectatorship serves a prophetic function as people are reminded by tragedy that many tragic situations should never have taken place in the first place. For instance, there is probably no story more tragic than that of Jephthah's Daughter when a joyous daughter goes out to meet

44 Nussbaum, Religious Intolerance, 140-143.

45 Martha Nussbaum, Political Emotions: Why Love Matters for Justice (Cambridge, MA: Harvard University Press, 2013), 258

46 Nussbaum, Political Emotions, 262-263

47 Nussbaum, Political Emotions, 272. 
her father who is returning victorious from war. Presumably dancing and singing as the women from that time did welcoming back the returning warriors, ${ }^{48}$ she does not know that her father had formerly made a vow to sacrifice as a burnt offering the one who would come out to meet him.

At first glance it seems impossible to think that one can read this tragic story in terms of human dignity. And yet Kathleen Sands makes a helpful observation regarding the importance of tragic stories in moral formation:

Tragedies tell of suffering, but they are something more than lebensschmerz. They are stories that narrate a specifically moral sort of catastrophe. Tragedies record the fundamental contradiction between reality and ideality: life is not as it should be; we are not as we should be. This contradiction is the birth trauma of moral consciousness, and each new blossom opens around the knowledge that the contradiction will outlive it. In repudiating some part of reality, some part of ourselves, tragedies convey a prereflective, negative moral judgment. ${ }^{49}$

Actually with reference to tragic stories such as Jephthah's daughter and the parallel Greek story of Iphigenia, the daughter of Agamemnon who is almost sacrificed by her father in order to appease the gods, Sands argues as follow:

Catastrophes such as killing one's daughter may stay in the theatre, but this is the one that follows us home - the catastrophe, not just of innoncent suffering, but of innocent fault. Tragic actors are morally faulted, yet in a way that could not have been avoided. And when we behold that fault and judge it, we simultaneously partake in it. So the faultedness, for all of us, is also an injustice we suffer. This is [the] heart of the tragic fault: to affirm our value is at once to stand against ourselves, and to affirm the world is at once to stand against it - not against our selves or the world in toto but against a brokenness that is, in the manner of trauma, ultimate. ${ }^{50}$

48 Carol Meyers, "Of Drums and Damsels: Women's Performance in Ancient Israel," Biblical Archaeologist 54 (1991): 16-27.

49 Kathleen M. Sands, “Tragedy, Theology, and Feminism in the Time after Time," in New Literary History 34 (2004): 43.

50 Sands, "Tragedy, Theology, and Feminism in Time after Time," 43. 
Tragedies thus play an important role in helping us recognize what is wrong in the world. As Nussbaum also rightly notes, "Tragedy is rarely just tragedy. Most often, behind the gloom is stupidity, or selfishness, or laziness, or malice." ${ }^{51}$ But by recognizing the fault amongst us and even in us, we are one step closer to preventing tragedies from occurring in the first place. ${ }^{52}$

Nussbaum in her book Political Emotions moreover includes a section on the role of ancient comedies, which she, together with tragedy, considers to be flipsides of the same coin. Like tragedy, comedy plays a vital role in communicating the very essence of human vulnerability. Often featuring elements that celebrate bodily nature such as references to excrement, sex, food and drink, Nussbaum argues that such comedic elements is a sign of human vulnerability that is "common to all, as just a part of being alive, connected to life's joy." 53

Within the biblical tradition someone like Mark Biddle has done some interesting work in showing how humor and comedy quite often has the function of identifying incongruities in life to which people otherwise may be blind - humor thus harbouring a truth-telling or prophetic dimension. ${ }^{54}$ Few stories are funnier in the Hebrew Bible than that of Jonah, the reluctant prophet who after refusing to take up his prophetic role, finds himself swallowed by a whale. This is after he accidentally converted the heathen sailors on the boat that he used to flee from God, and before he without really trying, saved 120000 Ninevites by the shortest repentance sermon in history - exactly those Ninevites that he had wanted to see destroyed. ${ }^{55}$

51 Nussbaum, Political Emotions, 271.

52 Cf. also Jacqueline Lapsley who argues that "part of the need to retain 'texts of terror' in the biblical witness is ....their painful mimetic quality: the reveal us to ourselves," Whispering the Word: Hearing Women's Stories in the Old Testament (Louisville, KY: Westminster John Knox, 2005), 9.

53 Nussbaum, Political Emotions, 272.

54 Mark E. Biddle, A Time to Laugh: Humor in the Bible (Macon, GA: Smyth \& Helwys, 2013), Loc 1334 of 2601.

55 Ibid. Cf. also J. William Whedbee, "Jonah as Joke: A Comedy of Contradiction, Caricature, and Compassion," in idem, The Bible and the Comic Vision (Cambridge: Cambridge University Press, 1998), 191-220. 
And then there are the cows. Biddle writes quite comically that he has come to understand the entire story of Jonah through the lens of cows. In the final chapter, one encounters the very funny image of repentant cows donned in sack cloth, mooing in lament. Biddle argues that the story of Jonah reveals incongruities such as that a prophet of Israel who on the one hand confesses that God is the Creator God who made the entire universe and then thinks he can flee away to Tarshish. Or a prophet who actually do not want to preach nor to see people repent. And the image of "converted cows" compellingly makes the point that God's love extends also to Israel's worst enemies and yes, even to their cows. ${ }^{56}$

Humor also has the further function to humanize the Other. Those Ninevites who in the text serve as stock figures and a symbol of all that is cruel and to be feared in Israel's history is portrayed as having cows. Indeed humor becomes a way of transcending boundaries by showing similarities among people - even and especially those people whom we consider to be other to us in terms of race, ethnicity and sexual orientation. ${ }^{57}$ In terms of the biblical tradition, a story like that of Jonah that draws on the comedic to transcend boundaries offers an important alternative to some of his contemporaries like Ezra and Nehemiah who come from the same period in time and who had some clear, and I would propose harmful, strategies for dealing with the "others" in their midst.

We thus see how comedy, like also tragedy mentioned earlier, plays a central role in forging a participatory imagination which as Nussbaum compellingly has shown holds the potential of offering a bridge to the universal. As Biddle points out, "satire comically tells the painful truth." ${ }^{58}$ The story of Jonah thus also identifies the "laughable incongruities" also

56 Biddle, A Time to Laugh, Loc 1345 of 2601.

57 Cf. also the work of Melissa Jackson on comedy in the biblical tradition, Comedy and Feminist Interpretation of the Hebrew Bible: A Subversive Collaboration (Oxford: Oxford University Press, 2012). For instance, she identifies quite a few comedic elements in the story of Rahab, one of the quintessential Others in Israel's history, when Rahab who is found on the margins of society uses cunning and wit in order to survive. In the process, she exposes the Israelite spies as fools, who are portrayed in quite humorous fashion as "buffoons" who end up in a brothel, (p86). As Jackson argues: "Rahab bests every man in control of this text: the king, the king's men, the spies, (....the inept one who chose them - Joshua), and even - despite their own efforts - the redactor(s)" (p94)

58 Biddle, A Time to Laugh, Loc 1345 of 2601. 
of our lives where we have trouble looking beyond our narrow circle of concern, understanding that God is a God who even forgives Assyrians and pities cows.

\section{Conclusion}

Reading the Bible for the dignity of all is a choice. In this paper, I have suggested some hermeneutical strategies that may help us accomplish this undertaking which is often easier said than done in terms of the messy situations that make up our everyday realities in which competing claims of justice vie for our attention.

Actually, what is at stake in this exercise of reading for the dignity for all is the question of how we can help our respective constituencies; in the case of university professors, our students; for pastors, our parishioners, to move from being compliant readers to conversant readers - categories introduced by Seibert in his book on "Overcoming the Old Testament's Troubling Legacy." 59

I have found that many of our new students experience this task to be quite challenging - as one student the other day in class aptly said: students come from communities of compliant readers and will return once more to such communities. He also mentioned that he was saddened by the fact that some of the pastors in his denomination, quite a few whom also have been our students, either never make this transition or revert back to a position of what is familiar and hence safe.

This raises the question for further reflection with which I conclude this paper: What does it take to teach conversant readers who will read the Bible for the dignity of all? And perhaps even more importantly, how can we as teachers ensure that this transformation from compliant to conversant

59 Seibert, The Violence of Scripture, 54-57. Seibert defines "compliant readers" as "individuals whose basic instinct is to read the Bible trustingly....They choose to agree with - and submit to - the Bible's assessment of things, even when this may be difficult to understand or morally troubling (p54)." Conversely, Seibert describes "conversant readers" as "readers who instead of "simply acquiescing to the text, their fundamental disposition is one of active engagement, sustained conversation, and critical evaluation (p56)." 
readers sticks, i.e., that we cultivate readers who, twenty years from now, still read the Bible for the dignity of all?

\section{Bibliography}

Avalos, Hector, Melcher, Sarah and Schipper, Jeremy (Eds). 2007. This

Abled Body: Rethinking Disabilities in Biblical Studies. Atlanta, GA:

Society of Biblical Literature.

Biddle, Mark E. 2013. A Time to Laugh: Humor in the Bible. Macon, GA:

Smyth \& Helwys.

Bosman, Hendrik. 2013. "Figuring God and Humankind: The Imago Dei in View of Anthropologies in the Old Testament," Pages 39-56 in Fragile Dignity: Intercontextual Conversations on Scriptures, Family and Violence. Edited by L Juliana Claassens and Klaas Spronk; Atlanta, GA: SBL.

Bowen, Nancy. 2006. "Women, Violence and the Bible." Pages 186-199 in Engaging the Bible in a Gendered World: An Introduction to Feminist Biblical Interpretation in Honor of Katharine Doob Sakenfeld. Edited by Linda Day and Carolyn Pressler. Louisville, KY: Westminster John Knox.

Claassens, L Juliana. 2012. "Resisting Dehumanization: Ruth, Tamar and the Quest for Human Dignity." Catholic Biblical Quarterly 74/4, 659674.

- 2013. "Countering Stereotypes: Job, Disability and Human Dignity." Journal of Religion, Disability \& Health 17/2, 169-183.

- 2013. "Just Emotions: Reading the Sarah and Hagar narrative (Genesis $16,21)$ through the Lens of Human Dignity." Verbum et Ecclesia 34/2, Art. \#787.

Daly, Mary. 1978. Gyn/Ecology: The Metaethics of Radical Feminism. London: Women's Press.

Day, Linda. 2000. "Rhetoric and Domestic Violence in Ezekiel 16." Biblical Interpretation 8, 205-229. 
Exum, Cheryl. 1995. "The Ethics of Biblical Violence against Women,"

Pages 248-271 in The Bible in Ethics: The Second Sheffield Colloquium.

Edited by John William Rogerson and Daniel Carroll. Sheffield: Sheffield Academic Press.

Farisani, Elelwani. 2014. "Interpreting the Bible in the Context of Apartheid and Beyond: An African Perspective." Studia Historiae Ecclesiasiticae 40/2, 207-225.

Fontaine, Carole R. 2008. With Eyes of Flesh: The Bible, Gender and Human Rights. Bible in the Modern World 10; Sheffield: Sheffield Phoenix Press, 2008.

Heard, Chris. 1997. "Hearing the Children's Cries: Commentary, Deconstruction, Ethics, and the Book of Habakkuk." Semeia 77, 75-89.

Honig, Bonnie. 1999. "Ruth the Model Emigree: Mourning and the Symbolic Politics of Immigration." Pages 50-74 in Ruth and Esther: A Feminist Companion to the Bible (Second Series). Edited by Athalya Brenner; Sheffield: Sheffield Academic Press.

Hoppe, Leslie J. 2004. There shall be No Poor Among You. Nashville, TN: Abingdon.

Hornsby, Theresa J. and Stone, Ken (Ed). 2011. Bible Trouble: Queer Reading at the Boundaries of Biblical Scholarship. Semeia Studies 67. Atlanta, GA: SBL.

Jackson, Melissa. 2012. Comedy and Feminist Interpretation of the Hebrew Bible: A Subversive Collaboration. Oxford: Oxford University Press.

Lapsley, Jacqueline. 2005. Whispering the Word: Hearing Women's Stories in the Old Testament. Louisville, KY: Westminster John Knox.

LeClerk, Thomas L. 2001. Yahweh is exalted in Justice: Solidarity and Conflict in Isaiah. Minneapolis, MN: Fortress.

Lombard, Christo. 2009. "Does Contextual Exegesis Require an Affirming Bible? Lessons from 'Apartheid' and 'Africa' as Narcissistic Hermeneutical Keys.” Scriptura 101, 274-287.

Loubser, J A (Bobby). 1987. The Apartheid Bible. Cape Town: Maskew Miller Longman. 
Mays, James Luther. 2006. "The Self in the Psalms and the Image of God." Pages 27-43 in God and Human Dignity. Edited by R Kendall Soulen \& Linda Woodhead; Grand Rapids, MI: Eerdmans,

Meyers, Carol. 1991. "Of Drums and Damsels: Women's Performance in Ancient Israel.” Biblical Archaeologist 54, 16-27.

Nussbaum, Martha C. 2012. The New Religious Intolerance: Overcoming the Politics of Fear in an Anxious Age. Cambridge, MA: Bellknap Press.

- 2013. Political Emotions: Why Love Matters for Justice (Cambridge, MA: Harvard University Press.

Russell, Letty M. 2006. “Twists and Turns in Paul's Allegory.” Pages 71-100 in Hagar, Sarah, and Their Children: Jewish, Christian, and Muslim Perspectives. Edited by Phyllis Trible and Letty M. Russell. Louisville, KY: Westminster John Knox.

Sakenfeld, Katharine Doob, 1999. Ruth. Interpretation. Louisville, KY: John Knox.

Sands, Kathleen M. 2004. "Tragedy, Theology, and Feminism in the Time after Time." New Literary History 34, 41-61

Schipper, Jeremy. 2006. Disability Studies and the Hebrew Bible: Figuring Mephibosheth in the David Story. New York, NY: T \& T Clark.

- 2011. Disability and Isaiah's Suffering Servant. Oxford, U.K.: Oxford University Press.

Schüssler Fiorenza, Elisabeth. 1988. "The Ethics of Biblical Interpretation: Decentering Biblical Scholarship.” JBL 107, 3-17.

Seibert, Eric. 2012. The Violence of Scripture: Overcoming the Old Testament's Troubling Legacy. Minneapolis: Fortress Press.

Shields, Mary E. 1998. "Multiple Exposures: Body Rhetoric and Gender Characterization in Ezekiel 16." JFSR 14, 5-18.

Spina, Frank. 2005. Faith of the Outsider: Exclusion and Inclusion in the Biblical Story. Grand Rapids, MI: Eerdmans. 
Stone, Ken. 2011. "Queer Reading between Bible and Film: Paris is Burning and the 'Legendary Houses' of David and Saul." Pages 75-98 in Bible Trouble: Queer Reading at the Boundaries of Biblical Scholarship. Edited by Theresa J. Hornsby and Ken Stone. Semeia Studies 67; Atlanta, GA: SBL.

Trible, Phyllis. 1984. Texts of Terror: Literary-Feminist Readings of Biblical Narratives. Philadelphia: Fortress Press.

Villalobos, Manuel. 2011. "Bodies Del Odro Lado Finding Life and Hope in the Borderland: Gloria Anzaldúa, the Ethiopian Eunuch of Acts 8:26-40, y Yo." Pages 191-222 in Bible Trouble: Queer Reading at the Boundaries of Biblical Scholarship. Edited by Theresa J. Hornsby and Ken Stone. Semeia Studies 67. Atlanta, GA: SBL.

Weems, Renita J. 1991. "Reading Her Way through the Struggle: African American Women and the Bible." Pages 61-62 in Stony the Road We Trod: African American Biblical Interpretation. Edited by Cain Hope Felder. Minneapolis: Fortress.

- 1995. Battered Love: Marriage, Sex, and Violence in the Hebrew Prophets. Minneapolis: Fortress Press.

Whedbee, J. William. 1998. "Jonah as Joke: A Comedy of Contradiction, Caricature, and Compassion." Pages 191-220 in idem, The Bible and the Comic Vision. Cambridge: Cambridge University Press.

Williams, Delores. 2006. "Hagar in African American Biblical Appropriation." Pages 171-184 in Hagar, Sarah, and Their Children: Jewish, Christian, and Muslim Perspectives. Edited by Phyllis Trible and Letty M. Russell; Louisville, KY: Westminster John Knox.

Zaru, Jean. 2010. "Biblical Teachings and the Hard Realities of Life." Pages 123-137 in Hope Abundant: Third World and Indigenous Women's Theology. Edited by Kwok Pui-lan; Maryknoll, NY: Orbis. 